\title{
PENGARUH MODEL PEMBELAJARAN PROBLEM BASED LEARNING (PBL) BERORIENTASI TRI HITA KARANA TERHADAP HASIL BELAJAR IPA
}

\author{
Ni Putu Tiarini ${ }^{1}$, Nyoman Dantes ${ }^{2}$, Kadek Yudiana ${ }^{3}$ \\ 1,3 Jurusan Pendidikan Dasar, ${ }^{2}$ Jurusan Bimbingan Konseling \\ Universitas Pendidikan Ganesha \\ Singaraja, Indonesia \\ e-mail: pututiarini19@gmail.com¹, dantes@undiksha.ac.id ${ }^{2}$, \\ kadek.yudiana@undiksha.ac.id ${ }^{3}$
}

\begin{abstract}
Abstrak
Penelitian ini bertujuan untuk mengetahui perbedaan hasil belajar IPA antara siswa yang mengikuti pembelajaran dengan menggunakan model pembelajaran Problem Based Learning dan siswa yang mengikuti pembelajaran konvensional pada siswa kelas V. Penelitian ini merupakan penelitian quasi experiment dengan desain Non-equivalen Post-test Only Control Group Desain. Populasi penelitian ini adalah seluruh kelas V SDN Gugus IV Kecamatan Banjar Tahun Pelajaran 2018/2019 berjumlah 139 siswa. Sampel pada penelitian ini diambil menggunakan teknik random sampling. Pengumpulan data dalam penelitian ini dilakukan dengan menggunakan metode tes. Data yang telah dikumpulkan dianalisis menggunakan statistik deskriptif dan inferensial uji-t independent (dengan beberapa asumsi terpenuhi). Berdasarkan ringkasan hasil Uji hipotesis dengan uji $\mathrm{t}$ berbantuan SPSS 25.0, diperoleh hasil bahwa signifikasi hasil belajar $0,002<0,05$, ini berarti bahwa terdapat perbedaan model pembelajaran Problem Based Learning berorientasi Tri Hita Karana terhadap hasil belajar IPA siswa kelas V semester II Gugus IV Kecamatan Banjar Tahun Pelajaran 2018/2019.
\end{abstract}

Kata-kata kunci : Problem Based Learning, Hasil Belajar IPA, Tri Hita Karana

\begin{abstract}
This research was aimed to know the differences the students' learning outcomes of Science between students who were taught by using Problem Based Learning model and who were taught by using conventional learning on student grade V. This research was a quasi-experiment research with Non-equivalent Post-test Only Control Group Design. The population of this research was 139 students of student grade $\mathrm{V}$ in elementary school group IV Banjar sub-district in the academic year of 2018/2019. By using random sampling technique, the sample was chosen. The data were collected by using test method. The collected data were analyzed by using descriptive statistic and inferential using t-test (with some assumption is fulfilled). Based on the summary of the result of the hypothesis test using t-test assisted SPSS 25.0, showed that the significance of the students' learning outcomes 0.002 which is lower than 0.05 , which is mean that there are differences the students' learning outcomes of Science between students who were taught by using Problem Based Learning model and who were taught by using conventional learning on student grade $\mathrm{V}$ in elementary school group IV Banjar sub-district in the academic year of 2018/2019
\end{abstract}

Keywords: Problem Based Learning, Learning Outcomes of Science, Tri Hita Karana 


\section{Pendahuluan}

Pendidikan merupakan sarana pembentuk manusia yang seutuhnya yang berjiwakan Pancasila, hal ini sesuai dengan tujuan dari pendidikan. Pendidikan adalah usaha sadar untuk menyiapkan peserta didik melalui kegiatan bimbingan, pengajaran, dan atau latihan bagi peranannya di masa yang akan datang. Sesuai dengan tujuan pendidikan nasional bangsa Indonesia yang tertuang dalam pembukaan UUD 1945 menyebutkan bahwa "Mencerdaskan Kehidupan Bangsa" hal ini menegaskan bahwa pemerintah ingin memberikan pendidikan yang baik bagi warganya. Sumber daya manusia yang berkualitas merupakan tumpuan utama agar bangsa Indonesia dapat melaksanakan pembangunan dan mampu bersaing dengan bangsa lain di era globalisasi ini. Pendidikan memiliki peran yang sangat penting dalam menghasilkan sumber daya manusia yang berkualitas. Oleh karena itu, lembaga pendidikan dituntut untuk meningkatkan kualitas pendidikannya sebagai upaya peningkatan kualitas sumber daya manusia.

Sekolah sebagai salah satu lembaga kependidikan bagi anak yang bertujuan untuk mengembangkan sikap, kemampuan, keterampilan, serta memberikan pengetahuan yang diperlukan untuk hidup di masyarakat. Tujuan tersebut dapat tercapai melalui pendidikan dan pengajaran dalam berbagai disiplin ilmu. Salah satu disiplin ilmu tersebut adalah IImu Pengetahuan Alam (IPA).

IPA merupakan konsep pembelajaran alam dan mempunyai hubungan yang sangat luas terkait dengan kehidupan manusia. Pembelajaran IPA sangat berperan dalam proses pendidikan dan juga perkembangan teknologi. IPA merupakan salah satu mata pelajaran yang harus dikuasai oleh siswa sebagai alat pendidikan yang berperan penting dalam meningkatkan mutu pendidikan, khususnya di dalam menghasilkan peserta didik yang mampu berpikir kritis, logis dan berinisiatif dalam menghadapi kemajuan IPTEK. Oleh karena itu IPA dimasukkan dalam kurikulum sekolah dasar.

Mata pelajaran IPA di Sekolah Dasar merupakan pembelajaran yang memuat materi tentang pengetahuan-pengetahuan alam yang dekat kaitanya dengan kehidupan peserta didik. IPA menekankan peserta didik mencari tahu dan berbuat sehingga dapat membantu peserta didik memperoleh pemahaman yang lebih mendalam tentang dirinya sendiri dan alam sekitar, serta prospek perkembangan lebih lanjut dalam menerapkanya dalam kehidupan sehari- hari. Dengan demikian maka melalui pembelajaran IPA siswa didorong untuk mempelajari alam disekitarnya secara kreatif yang pada akhirnya mereka bisa berfikir kritis, mengingat Pembelajaran IPA menyediakan berbagai pengalaman belajar untuk memahami berbagai konsep dan proses sains, Keterampilan proses dilaksanakan melalui: prosedur pemecahan masalah

Akan tetapi pembelajaran IPA masih memiliki banyak kendala dalam pelaksanaannya. Terbatasnya sarana dan prasarana menyebabkan guru dalam setiap proses pembelajaran hanya mengandalkan pengetahuannya saja bahkan dalam penggunaan metode belajar yang kurang tepat. Salah satu metode yang sampai saat ini masih banyak digunakan guru dalam mengajar yaitu metode pembelajaran konvensional (tradisional). Metode yang dalam penyampaian materinya dengan cara ceramah, sehingga guru lebih bersifat aktif, sedangkan peserta didik hanya duduk dan mendengarkan penjelasan guru. Daya serap materinya pun tidak bertahan lama, karena hanya mengandalkan aspek pendengaran.

Pembelajaran IPA di sekolah dasar memerlukan inovasi agar dapat meningkatkan kemampuan berpikir tingkat tinggi siswa. Berdasarkan observasi dan wawancara yang telah dilakukan pada tanggal 14 Januari 2019 di kelas V gugus IV kecamatan Banjar, guru masih menggunakan cara mengajar yang konvensional dan cenderung menggunakan metode ceramah. Selain menerapkan metode ceramah, guru juga memberikan latihan-latihan soal saja. Hasil wawancara pada 14 Januari 2019 yang dilakukan juga menunjukkan bahwa penggunaan model-model pembelajaran inovatif cenderung masih jarang. Metode pembelajaran yang sering digunakan adalah metode ceramah. Berdasarkan hasil pengamatan, pembelajaran masih berpusat pada guru karena guru kurang dalam hal melibatkan siswa dalam pembelajaran. Guru cenderung menjelaskan dengan metode ceramah dan memberikan 
soal kepada siswa setelah selesai menjelaskan materi. Hal tersebut berdampak pada hasil belajar IPA siswa yang rendah.

Berdasarkan permasalahan tersebut, diperlukan suatu inovasi pembelajaran yang dapat meningkatkan hasil belajar IPA siswa. Salah satunya dengan menerapkan model pembelajaran Problem Based Learning (PBL). Pada dasarnya, Problem Based Learning (PBL) merupakan model pembelajaran dengan penyajian masalah sebagai sumber belajar. Problem Based Learning (PBL) mendorong siswa untuk berusaha mencari pemecahan masalah, sehingga pengetahuan yang menyertainya mampu menghasilkan pengetahuan yang benar-benar bermakna (Hiderasti et al., 2013:14)

Model pembelajaran Problem Based Learning (PBL) menuntut siswa untuk memecahkan masalah yang ada dengan bekerja kelompok atau tim sehingga siswa lebih aktif dalam pembelajarannya. Siswa diberikan kebebasan untuk aktif berpartisipasi mengembangkan pemikirannya dalam materi yang diajarkan serta mampu menggunakannya dalam menyelesaikan permasalahan dari sebuah fenomena yang ada dalam kehidupan seharihari (Rukmana et al., 2012:3). Penggunaan model ini melibatkan siswa untuk aktif dalam belajar, sehingga memberikan kontribusi pada peningkatan hasil belajar siswa. Hal tersebut sejalan dengan penelitian yang dilakukan oleh Hanifah (2018) yang berjudul "Pengaruh Model Pembelajaran Problem Based Learning (PBL) terhadap Hasil Belajar Pembelajaran Terpadu Mata Pelajaran IPA Peserta Didik Kelas IV SD N 1 Labuhan Ratu". Hasil penelitiannya menunjukkan bahwa, model pembelajaran Problem Based Learning (PBL) berpengaruh terhadap hasil belajar IPA peserta didik kelas IV SD Negeri 1 Labuhan Ratu. Menurut penelitian yang dilakukan Made Gautama Jayadiningrat (2018) penerapan Problem Based Learning dapat meningkatkan keterampilan memecahkan masalah pada mata pelajaran Kimia

Namun selain penerapan model pembelajaran Problem Based Learning, pembelajaran juga perlu dikaitkan dengan Tri Hita Karana. Wiana, (2007: 5) menyatakan "Tri Hita Karana berasal dari bahasa sansekerta, istilah Tri Hita Karana berasal dari kata Tri yang artinya tiga (3), Hita artinya bahagia dan Karana Penyebab. Dengan demikian Tri Hita Karana merupakan tiga penyebab kebahagiaan". Nama Tri Hita Karana inilah yang dijadikan judul untuk menyebutkan ajaran yang mengajarkan agar manusia mengupayakan hubungan harmonis dengan Tuhan, dengan sesama manusia dan dengan alam lingkungannya. Bagian-bagian Tri Hita karana menurut Wiana (2007: 8) yaitu, Pahrayangan, Palemahan, dan Pawongan. Pahrayangan adalah tempat pemujaan hindu sebagai media bagi umat hindu untuk menghubungkan diri tengan Tuhan. Pawongan adalah media untuk membangun hubungan harmonis dengan sesama manusia, sedangkan Palemahan adalah media untuk membangun hubungan yang penuh kasih manusia dengan alam lingkungannya.

Penerapan Tri Hita Karana tersebut dapat dikaitkan dengan penerapan model pembelajaran Probem Based Learning (PBL). Bagian Tri Hita Karana yang pertama yaitu Parhyangan, dapat kita lihat ketika tahapan awal penerapan model pembelajaran Probem Based Learning (PBL) yaitu berdoa sebelum memulai pembelajaran. Kemudian Pawongan dapat dilihat pada tahapan model pembelajaran Probem Based Learning (PBL) ketika pembentukan kelompok, yaitu siswa diharapkan saling menghargai pendapat antar anggota kelompok untuk membina hubungan yang harmonis antar sesama anggota kelompok. Sedangkan penerapan Palemahan dapat dilihat ketika pembelajaran IPA yang mempelajari tentang alam dengan menggunakan model pembelajaran Probem Based Learning (PBL). Pada pembelajaran IPA siswa diajarkan untuk dapat peduli terhadap lingkungan sekitar sehingga tercipta hubungan yang harmonis antara alam dengan lingkungan. Berdasarkan latar belakang di atas, dirasa penting untuk melakukan penelitian dengan judul "Pengaruh Model Pembelajaran Problem Based Learning (PBL) Berorientasi Tri Hita Karana terhadap Hasil Belajar IPA Siswa.

Adapun tujuan yang ini dicapai dalam penelitian ini adalah Untuk mengetahui perbedaan hasil belajar IPA siswa yang mengikuti Model Pembelajaran Problem Based Learning (PBL) Berorientasi Tri Hita Karana dengan siswa yang mengikuti model pembelajaran konvensional pada siswa. 


\section{Metode}

Penelitian ini adalah eksperimen semu maka bentuk desain eksperimen semu (quasy experimental design) yang digunakan dalam penelitian ini yaitu non-equivalent post-test control group design. Rancangan tersebut dipilih karena tujuan dari penelitian ini adalah mengetahui perbedaan hasil belajar siswa yang terjadi setelah model pembelajaran Problem Based Learning berorientasi Tri Hita Karana dibelajarkan pada siswa. Pada rancangan non-equivalent post-test only control group design terdapat dua kelompok yang dipilih secara random dengan masing-masing sebagai kelas eksperimen dan kelas kontrol. Hal ini akan menunjukkan dengan jelas perbedaan yang terjadi berkaitan dengan hasil belajar IPA siswa di kelas. Populasi pada penelitian adalah seluruh siswa semester II kelas V yang terdapat pada Gugus IV Kecamatan Banjar Kabupaten Buleleng 2018/2019. Sebaran populasi dimasing-masing sekolah yang akan diteliti dapat dilihat dalam bentuk Tabel 1

Tabel 1. Sebaran Data Populasi

\begin{tabular}{cccc}
\hline No & Nama Sekolah & Kelas & Jumlah siswa \\
\hline 1 & SDN 1 Banjar & $\mathrm{V}$ & 24 \\
2 & SDN 3 Banjar & $\mathrm{V}$ & 16 \\
3 & SDN 5 Banjar & $\mathrm{V}$ & 12 \\
4 & SDN 6 Banjar & $\mathrm{V}$ & 12 \\
5 & SDN 7 Banjar & $\mathrm{V}$ & 24 \\
6 & SDN 8 Banjar & $\mathrm{V}$ & 28 \\
7 & SDN 9 Banjar & $\mathrm{V}$ & 12 \\
8 & SDN 10 Banjar & $\mathrm{V}$ & 11 \\
\hline
\end{tabular}

Sebelum menentukan sampel, perlu dilakukan uji kesetaraan. Uji kesetaraan dilakukan untuk menentukan sekolah mana saja yang layak digunakan sebagai sampel dalam penelitian ini. Uji kesetaraan penelitian ini menggunakan rumus ANAVA A dengan tarif signifikan $5 \%$. Kriteria pengujian dengan menggunakan analisis varians satu jalur (Anava $A$ ), jika $f_{\text {hitung }} \geq f_{\text {tabel }}$ maka $\mathrm{H}_{0}$ ditolak dan $\mathrm{H}_{1}$ diterima sehingga kelompok tidak setara. Jika $f_{\text {hitung }} \leq \mathrm{f}_{\text {tabel }}$ maka $\mathrm{H}_{0}$ diterima dan $\mathrm{H}_{1}$ ditolak sehingga kelompok setara. Dengan db pembilang (a-1) dan db penyebut $(\mathrm{N}-\mathrm{a})$ dan taraf signifikan $5 \%$.

Sampel dalam penelitian ini diambil dari populasi terjangkau dengan teknik Random Sampling dan dari hasil pengacakan diperoleh siswa kelas V di SD Negeri 1 Banjar dan SD Negeri 8 Banjar.

Perlakuan yang akan diberikan adalah dibelajarkan model pembelajaran Problem Based Learning berorientasi Tri Hita Karana pada kelompok eksperimen, sedangkan pada kelompok kontrol dibelajarkan dengan pembelajaran konvensional. Pembelajaran konvensional yang dimaksud pada penelitian ini adalah pembelajaran rutin dan dilakukan secara terus menerus dengan tahapan pembelajaran yang sederhana, yaitu tahap pembuka pada tahap ini guru tidak melaksanakan apersepsi, untuk kegiatan inti siswa mencatat apa yang sampaikan oleh guru sehingga dalam proses pembelajaran jarang dilibatkan bahkan kegiatan kelompok tidak pernah dilaksanakan, dan kegiatan penutup guru tidak pernah melaksanakan evaluasi. Berdasarkan kegiatan yang dilakukan pembelajaran konvesional adalah proses pembelajaran yang terjadi, guru sebagai pemegang kendali penuh dalam pembelajaran tanpa memperhatikan aktivitas siswa. Setelah pemberian perlakuan selesai akan diadakan post-test untuk mengukur hasil belajar IPA siswa kelas V di SD Gugus IV Kecamatan Banjar.

Pengumpulan data dalam penelitian ini meliputi data Hasil belajar IPA siswa kelas V di gugus IV kecamatan Banjar. Dalam penelitian ini data hasil belajar IPA di ukur menggunakan tes pilihan ganda. Sebelum instrument digunakan, terlebih dahulu dilakukan uji pakar untuk 
melihat kualitas isi dari instrument, kemudian instrument di ujikan ke beberapa orang siswa untuk mementukan validitas tiap butir soal yang akan diuji dengan menggunakan korelasi Point Biserial, uji reliabilitas menggunakan KR-21, uji tingkat kesukaran, dan diuji daya bedanya. Berdasarkan hasil uji coba intrumen, diperoleh dari 40 soal yang diujikan dan akan digunakan sebagai instrument posttest.

Data yang diperoleh dari penelitian ini adalah data kuantitatif berupa skor hasil belajar IPA siswa kelas V. Data yang diperoleh diuji secara deskritif yang terdiri dari perhitungan mean, median modus, standar deviasi, varians, maksimum, minimum, dan jangkauan, serta secara inferensial untuk pengujain hipotesis yang diajukan. Sebelum melakukan pengujian hipotesis, terlebih dahulu dilakukan uji prasyarat yaitu uji normalitas dan uji homogenitas. Pengujian normalitas sebaran data dilakukan dengan Uji normalitas data dilakukan untuk mengetahui data yang dihasilkan berdistribusi normal atau tidak. Uji normalitas ini menggunakan kolmogorov smirnov dengan bantuan SPSS 25.0 for windows. Uji ini dilakukan terhadap data post-test terhadap kelompok eksperimen dan kelompok kontrol. Apabila nilai signifikansinya lebih besar dari 0,05 (5\%) maka sampel yang berasal dari populasi berdistribusi normal, apabila nilai signifikansi lebih kecil dari 0,05 (5\%) maka sampel yang berasal dari populasi berdistribusi tidak normal. Pengujian homogenitas data dilakukan dengan Uji homogenitas varian yang digunakan adalah uji Levence's test of Equality of error Varians. Adapun kriteria pengujian homogenitas yaitu: (1) nilai signifikansi $<0,05$, maka data mempunyai varian yang tidak sama/tidak homogen, (2) nilai signifikansi $>0,05$, maka data mempunyai varian yang sama/homogen. Pengujian hipotesis dilakukan denggan menggunakan Uji-t. Hipotesis yang diuji adalah terdapat perbedaan hasil belajar IPA yang antara kelompok siswa yang dibelajarkan menggunakan model pembelajaran Problem Based Learning berorientasi Tri Hita Karana kelompok siswa yang hanya dibelajarkan dengan pembelajaran konvesional.

\section{Hasil dan Pembahasan}

Data yang diperoleh dari hasi penelitian ini adalah data hasil belajar IPA siswa pada kelas eksperimen dan kontrol yang diperoleh dari hasil pemberian posttest. Pada tabel 2 berikut akan disajikan rangkuman hasil analisis deksritif, skor hasil belajar siswa pada kelompok eksperimen dna kontrol.

Tabel 2. Analisis Deskritif Data Hasil Penelitian

\begin{tabular}{clcc}
\hline \multirow{2}{*}{ No } & & \multirow{2}{*}{ Hasil Analisis } & \multicolumn{2}{c}{ Hasil Belajar IPA } \\
\cline { 3 - 4 } & & Eksperimen & Kontrol \\
\hline 1 & Mean & 24 & 28 \\
2 & Median & 23,4 & 20 \\
3 & 23,4 & 19,8 \\
4 & Modus & 23,2 & 19,8 \\
5 & Standar Deviasi & 3,83 & 3,68 \\
6 & Varian & 14,69 & 13,52 \\
7 & Skor Maksimal & 30 & 27 \\
8 & Skor Minimal & 16 & 13 \\
\hline
\end{tabular}

Berdasarkan data tersebut, skor rata-rata hasil belajar IPA pada kelompok eksperimen melalui model pembelajaran Problem Based Learning berorientasi Tri Hita Karana, lebih tinggi dari kelompok kontrol dengan model pembelajaran konvensional.

Sebelum melakukan pengujian hipotesis data yang diperoleh terlebih dahulu dilakukan uji normalitasnya. Hasil pengujian normalitas data hasil belajar IPA siswa kelas eksperimen dan kontrol dapat dilihat pada tabel 3 berikut. 
Tabel 3. Uji Normalitas Data Hasil Penelitian

\begin{tabular}{clccc}
\hline \multirow{2}{*}{ No } & \multirow{2}{*}{ Normalitas Data } & \multicolumn{2}{c}{ Hasil Belajar IPA } \\
\cline { 3 - 4 } & & Eksperimen & Kontrol \\
\hline 1 & Dfatistik & 0,102 & 0,103 \\
2 & Df & 24 & 28 \\
3 & Sig & 0,200 & 0,2000 \\
\hline
\end{tabular}

Berdasarkan hasil uji normalitas hasil belajar IPA kelompok eksperimen dan kelompok kontrol di atas, dapat dilihat bahwa signifikansi hasil belajar IPA kelompok eksperimen dan kelompok kontrol 0,200 >0,05. Hal ini menunjukkan bahwa sebaran data hasil belajar IPA kelompok eksperimen dan kontrol berdistribusi normal.

Uji homogenitas varians antar kelompok bertujuan untuk memeriksa kesamaan varians antar kelompok perlakuan. Dalam penelitian ini, uji homogenitas dilakukan terhadap varians pasangan antar kelompok eksperimen dan kontrol. Rekapitulasi hasil uji homogenitas varians antar kelompok eksperimen dan kontrol disajikan pada 4 berikut.

Tabel 4. Rangkuman Hasil Uji Homogenitas Varians

\begin{tabular}{cccc}
\hline Data & Based on Mean & Signifikansi & Kesimpulan \\
\hline Hasil Belajar Bahasa Inodnesia & 0,899 & 0,05 & Homogen \\
\hline
\end{tabular}

Berdasarkan hasil uji homogenitas varians dengan bantuan SPSS 25.0, diperoleh hasil Based on Mean memiliki signifikansi 0,899 > 0,05. Hal ini menunjukkan data hasil belajar IPA memiliki varian yang homogen.

Dari hasil uji prasyarat yaitu uji normalitas dan uji homogenitas, diperoleh bahwa data hasil belajar IPA dari kelompok eksperimen dan kelompok kontrol berdistribusi normal dan homogen. Berdasarkan hal tersebut, dilanjutkan pada pengujian hipotesis penelitian atau hipotesis alternatif $\left(\mathrm{H}_{1}\right)$ yang telah dibahas pada kajian teori. Dalam penelitian ini diuji hipotesis yaitu sebagai berikut.

$$
\begin{array}{cc}
\mathrm{H}_{0} & : \mu_{1}=\mu_{2} \\
\mathrm{H}_{1} & : \mu_{1} \neq \mu_{2}
\end{array}
$$

Keterangan :

$\mathrm{H}_{0}$ : Tidak perbedaan hasil belajar IPA siswa yang mengikuti model pembelajaran Problem Based Learning (PBL) berorientasi Tri Hita Karana dengan siswa yang mengikuti model pembelajaran konvensional pada siswa kelas V semester II di Gugus IV Kecamatan Banjar Tahun Pelajaran 2018/2019.

$\mathrm{H}_{1}$ : Terdapat perbedaan hasil belajar IPA siswa yang mengikuti model pembelajaran Problem Based Learning (PBL) berorientasi Tri Hita Karana dengan siswa yang mengikuti model pembelajaran konvensional pada siswa kelas V semester II di Gugus IV Kecamatan Banjar Tahun Pelajaran 2018/2019. 
Adapun ringkasan hasil uji hipotesis dengan bantuan SPSS 25.0 dapat dilihat pada tabel berikut ini.

Tabel 5. Hasil Pengujian Hipotesis

\begin{tabular}{llccc}
\hline & T & Df & Sig. (2-tailed \\
\hline \multirow{2}{*}{ Hasil Belajar } & $\begin{array}{l}\text { Equal variances } \\
\text { assumed }\end{array}$ & 3,242 & 50 & 0,002 \\
& $\begin{array}{l}\text { Equal variances not } \\
\text { assumed }\end{array}$ & 3,231 & 48,101 & 0,002 \\
\hline
\end{tabular}

Berdasarkan ringkasan hasil Uji hipotesis dengan uji t berbantuan SPSS 25.0, diperoleh hasil bahwa signifikasi hasil belajar $0,002<0,05$, yang artinya $\mathrm{H}_{0}$ ditolak dan $\mathrm{H}_{1}$ diterima. Hal ini menunjukkan terdapat perbedaan hasil belajar IPA siswa yang mengikuti model pembelajaran Problem Based Learning (PBL) berorientasi Tri Hita Karana dengan siswa yang mengikuti model pembelajaran konvensional pada siswa kelas V semester II di Gugus IV Kecamatan Banjar Tahun Pelajaran 2018/2019.

Berdasarkan hasil uji hipotesis, diperoleh hasil yaitu terdapat perbedaan hasil belajar IPA siswa yang mengikuti model pembelajaran Problem Based Learning (PBL) berorientasi Tri Hita Karana dengan siswa yang mengikuti model pembelajaran konvensional pada siswa kelas V semester II di Gugus IV Kecamatan Banjar Kabupaten Buleleng Tahun Pelajaran 2018/2019. Siswa yang mengikuti model pembelajaran Problem Based Learning (PBL) berorientasi Tri Hita Karana memperoleh skor hasil belajar IPA yang lebih tinggi dibandingkan model pembelajaran konvensional. Hal ini disebabkan karena menyajikan berbagai permasalahan nyata dalam kehidupan sehari-hari siswa (bersifat kontekstual) sehingga merangsang siswa untuk belajar. Masalah sebagai landasan awal untuk membangun kemampuan berpikir kritis siswa dengan terampil memecahkan masalah. Masalah yang disajikan adalah masalah yang memiliki konteks dengan dunia nyata, sehingga mampu mendorong siswa untuk berpikir secara aktif sesuai dengan pengalaman yang pernah dialami.

Pernyataan tersebut didukung oleh tujuan model pembelajaran PBL Menurut Yamin (2013:63-64) bahwa tujuan model PBL adalah untuk membantu siswa mengembangkan pengetahuan fleksibel yang dapat diterapkan dalam situasi yang berlawanan dengan inert knowledge. Inert knowledge yakni siswa tampak menguasai banyak pengetahuan faktual tetapi sebenarnya mereka tidak memahaminya secara mendalam atau tidak menyatukan atau tidak mengorganisasikannya secara sistematis dengan konteks pengalaman sehari-hari. PBL bukan menyampaikan sejumlah besar pengetahuan kepada siswa, melainkan pada pengembangan kemampuan berpikir kritis dan kemampuan siswa untuk secara aktif membangun pengetahuan sendiri. Pendapat tersebut sejalan dengan pendapat Trianto (2009: 94-95) yang menyatakan PBL memiliki tujuan: 1) membantu siswa mengembangkan keterampilan berpikir dan keterampilan pemecahan masalah. 2) belajar peranan orang dewasa yang autentik. 3) menjadi pembelajar yang mandiri.

PBL memberikan pembelajaran bermakna kepada siswa sehingga pembelajaran mudah dipahami siswa. Hal ini juga dilatarbelakangi oleh kelebihan model PBL menurut Trianto (2009:96) yaitu a) realistik dengan kehidupan siswa, b) konsep sesuai dengan kebutuhan siswa, c) memupuk sifat inquiry siswa, d) retensi konsep jadi kuat, dan e) memupuk kemampuan Problem Solving.

Pembelajaran dengan model PBL akan lebih efektif apabila diorientasikan dengan Tri Hita Karana. Tri Hita Karana inilah yang di jadikan judul untuk menyebutkan ajaran yang mengajarkan agar manusia mengupayakan hubungan harmonis dengan Tuhan, dengan sesama manusia dan dengan alam lingkungannya. Adapun bagian dari Tri Hita Karana yaitu Parhyangan, Pawongan, dan Palemahan. Parhyangan merupakan hubungan manusia dengan Tuhan. Dalam hal ini siswa diharapkan dalam mengikuti proses pembelajaran agar memiliki rasa syukur kepada Tuhan yang telah memberikan kesempatan untuk bisa melaksanakan pembelajaran dan berdoa agar pembelajaran berjalan dengan lancar. Kedua, Pawongan yaitu 
hubungan yang harmonis antar sesama manusia. Pada bagian ini siswa diharapkan dapat menjalin interaksi dengan sesama siswa, guru, dan seluruh warga sekolah. Ketiga, Palemahan yaitu hubungan yang harmonis antara manusia dengan lingkungan sekitarnya. Bagian ini mengharapkan siswa memiliki rasa peduli dengan lingkungan sekitarnya, terutama lingkungan sekolah tempat belajar. Jadis siswa ke sekolah tidak hanya belajar, namun juga melakukan kegiatan peduli lingkungan, seperti melaksanakan tugas piket membersihkan ruang kelas, membersihkan halaman sekolah, dan hal lainnya yang mencerminkan kegiatan cinta lingkungan. Dalam pembelajaran juga dapat diimplementasikan dengan mengaitkan pembelajaran dengan kegiatan peduli lingkungan. Berdasarkan pernyataan tersebut, maka tepatlah model pembelajaran PBL diorientasikan dengan Tri Hita Karana.

Adapun langkah model pembelajaran PBL berorientasi Tri Hita Karana yang telah diterapkan siswa kelas V semester II di Gugus IV Kecamatan Banjar yaitu berdoa sebelum memulai pelajaran (Pahrayangan). Siswa bersama guru berdoa bersama sebelum memulai pelajaran untuk membina hubungan yang harmonis antara manusia dengan Tuhan. Kemudian memasuki tahap pembelajaran PBL yang pertama yaitu Orientasi siswa pada masalah. Pada tahap ini siswa mendengarkan penjelasan guru mengenai tujuan pembelajaran, logistik yang diperlukan dan terlibat pada aktivitas pemecahan masalah. Tahap kedua yaitu mengorganisasikan siswa untuk belajar. Pada tahap ini siswa mendefinisikan dan mengorganisasikan tugas belajar yang berhubungan dengan masalah yang diberikan oleh guru. Tahap ketiga yaitu, membimbing pengalaman individu/kelompok (pawongan dan palemahan). Pada tahap ini siswa secara berkelompok mengumpulkan informasi yang sesuai, melaksanakan eksperimen untuk mendapatkan penjelasan dan pemecahan masalah yang berkaitan dengan gejala alam dalam pembelajaran IPA dengan saling menghargai pendapat teman dalam kelompok. Tahapan pembelajaran ini berkaitan dengan pawongan dan palemahan karena dalam proses diskusi kelompok siswa harus saling menghargai pendapat sesama anggota kelompok, menjalin komunikasi yang baik dengan anggota kelompok, serta mengerjakan tugas sama rata dengan anggota kelompok yang mencerminkan pawongan. Selain itu selama proses pembelajaran siswa diharuskan menjaga kebersihan kelas. Apabila ada sampah yang berserakan di sekitar tempat siswa belajar agar segera dipungut. Siswa juga tidak diperkenankan membuang kertas sembarangan. Palemahan ini juga dapat diterapkan pada materi pembelajaran yang diberikan mengenai perubahan yang terjadi di alam dan hubungannya dengan penggunaan sumber daya alam. Pada materi tersebut siswa diminta menganalisis penggunaan sumber daya alam yang baik sehingga tidak menghabiskan sumber daya alam dan menyebabkan perubahan yang berdampak negatif terjadi di alam.

Berbeda dengan model pembelajaran konvensional pada tahapan pembelajarannya lebih banyak menggunakan metode ceramah dan komunikasi hanya bersifat satu arah. Siswa hanya diberikan latihan soal dari buku yang telah disediakan. Siswa kurang diberikan kesempatan untuk berinteraksi dengan temannya. Hal ini membuat siswa kurang bersemangat dalam menerima pembelajaran, sehingga mempengaruhi hasil belajar IPA siswa. Hal inilah yang menyebabkan hasil belajar IPA siswa yang menggunakan model konvensional menjadi rendah.

Keberhasilan model pembelajaran PBL berorientasi Tri Hita Karana terhadap hasil belajar IPA didukung oleh hasil penelitian yang dilakukan oleh penelitian yang dilakukan oleh Hanifah (2018) yang berjudul "Pengaruh Model Pembelajaran Problem Based Learning (PBL) terhadap Hasil Belajar Pembelajaran Terpadu Mata Pelajaran IPA Peserta Didik Kelas IV SD N 1 Labuhan Ratu". Hasil penelitiannya menunjukkan bahwa, model pembelajaran Problem Based Learning (PBL) berpengaruh terhadap hasil belajar IPA peserta didik kelas IV SD Negeri 1 Labuhan Ratu.

Berdasarkan pembahasan di atas maka model pembelajaran PBL berorientasi Tri Hita Karana berpengaruh dalam peningkatan hasil belajar IPA siswa kelas V semester II Gugus IV Kecamatan Banjar Tahun Pelajaran 2018/2019. Berdasarkan hasil penelitian dan pembahasan yang telah dijelaskan, implikasi dari penelitian ini terdiri dari implikas teoretis dan implikasi praktis. Adapun implikasi teoretis dalam penelitian ini yaitu pemilihan model pembelajaran yang tepat berpengaruh terhadap hasil belajar IPA siswa. 
Sedangkan implikasi praktis dalam penelitian ini yaitu 1) memberikan kesempatan bagi guru SD untuk mengembangkan kemampuan mengajar dengan menggunakan model pembelajaran yang tepat untuk membangkitkan semangat belajar siswa sehingga tujuan pembelajaran dapat tercapai, yang dapat dilihat dari hasil belajar siswa yang meningkat. 2) memberikan masukan bagi sekolah untuk dapat meningkatkan mutu pendidikan di sekolah tersebut dengan menentukan kebijakan berupa penerapan model pembelajaran inovatif dalam pelaksanaan pembelajaran.

\section{Simpulan dan Saran}

Berdasarkan hasil pengujian hipotesis dan pembahasan, maka simpulan dari penelitian ini adalah sebagai berikut: Terdapat perbedaan hasil belajar IPA antara siswa yang mengikuti model pembelajaran Problem Based Learning Berorientasi Tri Hita Karana dan siswa yang mengikuti model pembelajaran Konvensional pada siswa kelas V SD Gugus IV Kecamatan Banjar. Rata-rata nilai hasil belajar IPA siswa yang dibelajarkan dengan model pembelajaran Problem Based Learning Berorientasi Tri Hita Karana sebesar 23,4 dan rata-rata hasil belajar IPA siswa yang menggunakan model pembelajaran Konvensional sebesar 20. Dari hasil uji hipotesis dengan uji t berbantuan SPSS 25.0, diperoleh hasil bahwa signifikasi hasil belajar $0,002<0,05$, yang artinya $\mathrm{H}_{0}$ ditolak dan $\mathrm{H}_{1}$ diterima. Hal ini menunjukkan Terdapat Perbedaan model pembelajaran Problem Based Learning Berorientasi Tri Hita Karana Terhadap Hasil Belajar IPA siswa kelas V semester II Gugus IV Kecamatan Banjar Tahun Pelajaran 2018/2019.

Berdasarkan penelitian yang telah dilakukan, saran yang dapat disampaikan adalah sebagai berikut. Siswa diharapkan selalu terlibat secara aktif dalam mengikuti proses pembelajaran, sehingga nantinya mendapatkan pengetahuan baru yang ditemukan sendiri sehingga hasil belajar dapat meningkat. Guru di dalam menyampaikan materi pelajaran hendaknya berinovasi dalam memilih model pembelajaran yang inovatif agar dapat mengatasi karakter siswa yang berbeda-beda. Kepada kepala sekolah, terutama di sekolah dasar hendaknya menjadikan model PBL sebagai model pembelajaran yang dapat di terapakan dalam pembelajaran di sekolah dasar, dan dapat dijadikan sebagai aturan guru dalam mengajar di dalam kelas. Peneliti lain yang akan melakukan penelitian lebih lanjut tentang model pembelajaran PBL berorientasi Tri Hita Karana dalam bidang pelajaran IImu Pengetahuan Alam maupun pelajaran yang lain agar memperhatikan kendala yang dialami di dalam penelitian ini, agar menjadi bahan pertimbangan untuk perbaikan dan penyempurnaan penelitian yang akan dilaksanakan.

\section{Daftar Pustaka}

Abidin, Yunus. 2014. Desain Sistem Pembelajaran dalam Konteks Kurikulum 2013. Bandung : Refika Aditama.

Agung, A. A G. 2014. Metodologi Penelitian Pendidikan. Singaraja: Aditya Media Publishing.

Agung, A. A. G. 2015. Statistika Dasar Untuk Pendidikan. Singaraja: Deepublish.

Agung, A. A. G. 2016. Statistika Inferensial. Singaraja: Fakultas IImu Pendidikan.

Aly, Abdullah dan Eni Rahma. 2008. Ilmu Alamiah Dasar. Jakarta : Bumi Aksara.

Bundu, Patta. 2006. Penilaian Keterampilan Proses dan Sikap Ilmiah dalam Pembelajaran Sains SD. Jakarta : Depdiknas. 
Candiasa, I Made. 2011. Pengujian Instrumen Penelitian Disertai Aplikasi ITEMAN dan BIGSTESP. Singaraja: Undiksha Press.

Dantes, Nyoman. 2017. Desain Eksperimen Dan Analisis Data. Depok: PT Raja Grafindo Persada.

Darmojo, Hendro dan J.R.F.Kaligis. 1992. Pendidikan IPA II. Jakarta : Depdikbud, Dirjen Dikti Proyek Pembinaan Tenaga Kependidikan.

Dewana, Aditya. 2017. "Pengaruh Model Problem Based Learning terhadap Hasil Belajar IPA Kelas IV SD". Jurnal Pendidikan dan Pembelajaran Untan. Tersedia pada https://media.neliti. com/media/publications/210452-none.pdf. Diakses pada 14 Februari 2019.

Dewi, N.M.J., D.K.N.S.Putra, dan N. Ganing. 2017. "Pengaruh Model Pembelajaran Problem Based Learning Berbantuan Media Audio Visual Animasi terhadap Hasil Belajar IPA". EJournal PGSD Universitas Pendidikan Ganesha. Vol. 5, No.2. Tersedia pada https://ejournal.undiksha. ac.id/index.php/JJPGSD/article/view/10657/6780. Diakses pada 14 Februari 2019.

Iskandar, Srini M. 1997. Pendidikan Ilmu Pengetahuan Alam. Jakarta : DIKTI.

Jayadiningrat, Made Gautama, and Emirensia K. Ati. "Peningkatan Keterampilan Memecahkan Masalah Melalui Model Pembelajaran Problem Based Learning (Pbl) Pada Mata Pelajaran Kimia." Jurnal Pendidikan Kimia Indonesia 2.1 (2018): 1-7.

Koentjaraningrat. 1993. Metode-metode Penelitian Masyarakat. Jakarta: Gramedia Pustaka Utama.

Komalasari, Kokom. 2011. Pembelajaran Kontekstual. Bandung : Refika Aditama.

Kurniasih, Imas. 2014. Sukses Mengimplementasikan Kurikulum 2013. Surabaya : Kata Pena.

Martini, Sri. 2017. "Pengaruh Model Problem Based Learning terhadap Hasil Belajar IPA Kelas V SDN 42 Pontianak Kota". Jurnal Pendidikan dan

Rasana, Raka. 2009. Model-model Pembelajaran. Laporan Sabbatical Leave. Singaraja: Undiksha.

Sani, R. A. 2014. Pembelajaran Saintifik untuk Implementasi Kurikulum 2013. PT Bumi Aksara, Jakarta.

Sanjaya, Wina. 2007. Strategi Pembelajaran Berorientasi Sandar Poses Pendidikan. Jakarta : Kencana.

Sawab, Baqiyatus. 2017. "Pengaruh Model Pembelajaran Problem Based Learning terhadap Hasil Belajar Siswa Kelas IV pada Mata Pelajaran IImu Pengetahuan Sosial di MI Mathla'ul Anwarsindang Sari Lampung Selatan". Skripsi Fakultas Tarbiyah dan Keguruan Universitas Islam Negeri Raden Intan Lampung. tersedia pada http://repository.radenintan.ac.id /1542/1/SKRIPSI_BAQIYATUS_SAWAB.pdf. Diakses pada 14 Februari 2019. 
Shoimin, Aris. 2014. 68 Model Pembelajaran Inovatif dalam Kurikulum 2013. Yogyakarta : ArRuzz Media.

Sudjana, N. 2010. Dasar-dasar Belajar Mengajar. Bandung: Sinar Baru Algensindo.

Suprijono, A. 2009. Cooperative Learning. Yogyakarta: Pustaka Pelajar.

Trianto. 2010. Model Pembelajaran Terpadu (konsep, strategi, dan implementasinya dalam KTSP). PT Bumi Aksara, Jakarta.

Wiana, Ketut. 2007. Cara Belajar Agama Hindu yang Baik. Denpasar : Yayasan Dharma Narada.

Windia,W.dan Dewi, R.K. 2011. Analisis Bisnis Berlandaskan Tri Hita Karana. Denpasar: Udayana University Prees

Wijayanti, Ni Luh Gede Suryani. 2015. "Pengaruh Model Pembelajaran Kooperatif Tipe TAI terhadap Hasil Belajar Matematika dengan Pengendalian Kecerdasan Logis Matematis pada Siswa Kelas VI SD Negeri di Gugus Mayor Metra Kecamatan Denpasar Utara". Tesis (tidak diterbitkan). Pendidikan Dasar, Pascasarjana, UNDIKSHA Singaraja.

Wonorahardjo, Surjani. 2010. Dasar-Dasar Sains. Jakarta : Indeks.

Yamin, Martinis. 2013. Strategi dan Metode dalam Model Pembelajaran. Jakarta : GP Press Group.

Sriwati,Ni. Luh. Gede. 2014. Penerapan Model Pembelajaran Course Review Horay Bebantuan Media Gambar Untuk Meningkatkan Kemampuan Bahasa Anak. e-Journal PG-PAUD Universitas Pendidikan Ganesha Jurusan Pendidikan Guru Pendidikan Anak Usia Dini, Vol. 2, No. 1.

Welle,Deutsche. 2017. Rangking Pendidikan Negara-Negara Asean. http://www.dw.com/id/rangking-pendidikan-negara-negara-asean/g-37594464/ Desember 2017). 